American Journal of Environmental Sciences 5 (1): 99-105, 2009

ISSN $1553-345 \mathrm{X}$

(C) 2009 Science Publications

\title{
Wastewater Treatment Using Horizontal Subsurface Flow Constructed Wetland
}

\author{
${ }^{1}$ S. Sarafraz, ${ }^{1}$ Thamer Ahamad Mohammad, ${ }^{1}$ Megat J. Megat M. Noor and ${ }^{2}$ A. Liaghat \\ ${ }^{1}$ Department of Civil Engineering, Faculty of Engineering, \\ University Putra Malaysia 43400 UPM Sedang, Selangor, Malaysia \\ ${ }^{2}$ Faculty of Water and Soil Engineering, University of Tehran, Tehran, Iran
}

\begin{abstract}
The last few decades witnessed sharp focus on environment pollution and its impact on life in nature. Wetlands can be used for biological treatment of wastewater. Problem statement: Scarcity of water is considered as a global problem and Iran is one the countries which is facing water shortage problem. Pollution of water bodies restrict the availability of water for various uses. Treatment of waste water before disposal contributes to water conservation efforts. Constructed wetlands are techniques aim to polish water quality and reduce the harmful effect of effluent. Approach: In this study, four horizontal subsurface flow wetlands (HSSF) were constructed at the Research Station of Tehran University, located in Karaj, Iran. The study was carried out from April to September, 2007. Gravel and zeoilte were used in this study as substrate. Gravel-beds with and without plants (called GP and G) and gravel-beds mixed with (10\%) zeolite, with and without plants (called ZP and Z) were examined to investigate the feasibility of treating synthetic wastewater which was specifically produced and modified to imitate agricultural wastewater. Results: The results of this study indicated that the system had acceptable pollutant removal efficiency and that both plants were found to be tolerant under the tested conditions. The wetland system could achieve the $\mathrm{NO}_{3}-\mathrm{N}$ removal of $(79 \%)$ in $\mathrm{ZP},(86 \%)$ in Z, (82\%) in GP and finally (87.94\%) in G. As for the P removal, the efficiencies of 93, 89,81 and $76 \%$ were respectively achieved for $\mathrm{ZP}, \mathrm{GP}, \mathrm{Z}$ and $\mathrm{G}$. The outflow concentrations of $\mathrm{Pb}$ and $\mathrm{Cd}$ were found to be under the detection limit; however, as for $\mathrm{Zn}$, the removal efficiencies of 99.9 , 99.76, 99.71 and $99.52 \%$ were concluded for ZP, Z, GP and G respectively. Conclusions/Recommendations: It can be concluded that constructed wetlands are efficient in removing $\mathrm{Zn}, \mathrm{Pb}$ and $\mathrm{Cd}$ from agricultural wastewater. Plants types such as Phragmites Australis and Juncus Inflexus can contribute in treating wastewater, while Zeolite and gravel materials provide a suitable plant growth medium to replace conventional sand and gravel substrates. So it is highly recommended to use Constructed wetland for treating wastewater before disposal.
\end{abstract}

Key words: Constructed Wetland, nitrate-nitrogen, phosphorus, wastewater, zeolite, $\mathrm{Zn}$

\section{INTRODUCTION}

Many countries around the world are experiencing water stress and scarcity during a large part of the year and they are exploiting reserves which are being not sufficiently replaced ${ }^{[1]}$. Iran is also going to experience water scarcity by 2025 , based on the availability of less than $1000 \mathrm{~m}^{3}$ of renewable water per person per year ${ }^{[2]}$. In addition to the natural scarcity of freshwater, the quality of the available freshwater is also getting worse; this is due to pollution which is a result of water shortage. Agricultural and residential wastewaters contain high levels of nutrients and if not treated, they can contaminate surface water and groundwater systems. The treatment of wastewater using Constructed Wetland (CW) is one of the treatment systems which are used in many parts of the world.
This system seems to have the potential to be one of the solutions in discharging the huge amount of wastes and getting access to safer drinking water. Constructed wetlands (CWs) are treatment systems that have been designed to accomplish natural processes containing wetland substrate, vegetation and the associated microbial assemblages to help in treating wastewaters and take advantage of the processes that occur in natural wetlands within a more controlled environment. Nitrogen $(\mathrm{N})$ and Phosphorus $(\mathrm{P})$ are the nutrients of concern for removal in wetland systems. The removal mechanisms for $\mathrm{N}$ include uptake by plants and microorganisms, ammonification, nitrification, denitrification, ammonia volatilization and cation exchange for ammonium ${ }^{[3]}$. The removal mechanisms for $\mathrm{P}$ include chemical adsorption and precipitation in substrate and biological transformations ${ }^{[4]}$ and also plant uptake in a lower percentages ${ }^{[5]}$.

Corresponding Author: S. Sarafraz, Department of Civil Engineering, Faculty of Engineering, Universiti Putra Malaysia, 43400 UPM Sedang, Selangor, Malaysia.email:sanaz_sarafraz@yahoo.com 


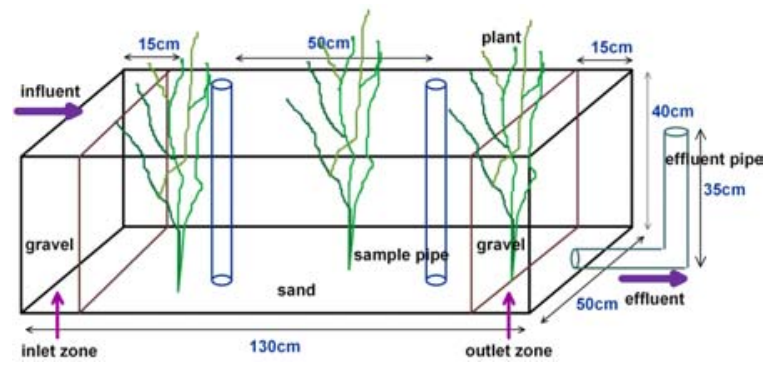

Fig. 1: Schematic 3D view of wetland cell

Industrialization in developing countries with an increasing demand for heavy metals results in a high emission of these pollutants into the biosphere. Heavy metal pollution in water bodies is a serious environmental problem, threatening the aquatic ecosystems and human health. Heavy metals are not degraded through biological processes. Some of the important heavy metals of concern in wastewaters are $\mathrm{Ni}, \mathrm{Mn}, \mathrm{Pb}, \mathrm{Cr}, \mathrm{Cd}, \mathrm{Zn}, \mathrm{Cu}, \mathrm{Fe}, \mathrm{Hg}$ and some toxic elements like As, B, Na. Among these we can mention functions of some them in $\mathrm{CW}$. The main objectives of this study were to determine the efficiency of the horizontal subsurface flow constructed wetland (HSSF) system in treating wastewater under the climatic condition in Iran and to determine the effect of gravel and zeolite as the media of treatment in constructed wetlands.

Materials and methods: In this study, four HSSF CWs systems made of polyethylene, each with a surface area of $0.65 \mathrm{~m}^{2}(1.3 \times 0.5 \mathrm{~m})$ and $0.4 \mathrm{~m}$ depth Fig 1 was conducted at Research Station of Tehran University, located in Karaj, Iran. A slope of (1\%) was required in placing the cells to maintain the hydraulic gradient. The inlet zone consisted of 4 inlet points (one for each cell) attached to a water control tank with a float installed after the storage tank and a container as a water source. The control structure was designed as the inlet water could enter with a constant head to maintain the water level in the system, as well as to avoid shock loading from the storage tank due to water level fluctuation in the tank. The outlet zone was made of perforated PVC pipes attached at the bottom of each cell. The edge of these pipes was connected to adjustable flexible hoses which served as risers for maintaining water level in the bed. Two perforated tubes covered with geotextile were inserted into the middle part of the substrate $40 \mathrm{~cm}$ apart from inlet and outlet to allow sampling. The gravel with the size of $10-15 \mathrm{~mm}$ was put into the inlet and outlet zones in each cell in order to produce a uniform distributed flow. Then the remainder area of two cells was filled with fine gravel and the other two with mixure of fine gravel and zeolite (10:1 weight ratio). An equal mixture of two plant species, Phragmites australis and Juncus inflexus for vegetation with an initial density of 30 plants $\mathrm{m}^{2}$ was selected for two cells (one with zeolite and one with gravel only). According to the types of substratum media and conditions with or without vegetation, four treatments were thus installed: gravel-beds with (10\%) zeolite (ZP) and without vegetation $(\mathrm{Z})$ and gravel-beds (GP) and without vegetation $(G)$. The influent for all four treatment systems was artificial wastewater prepared prior to each feeding by mixing urea $\left(\mathrm{NH}_{2}\right)_{2} \mathrm{CO}$ and Ammonia phosphate $\left(\mathrm{NH}_{4}\right)_{3} \mathrm{PO}_{4}$ as chemical fertilizers used in agriculture. Such synthetic wastewater contained approximately $80-100 \mathrm{mg} \mathrm{L}{ }^{1}$ of $\mathrm{NO}_{3}$ and 10 $\mathrm{mg} \mathrm{L^{1 }}$ of TP, 1,2 and $10 \mathrm{mg} \mathrm{\textrm {L } ^ { 1 }}$ of $\mathrm{Cd}, \mathrm{Pb}$ and $\mathrm{Zn}$ respectively. The required chemicals were mixed in $1000 \mathrm{~L}$ polyethylene container, using tap water. A valve was used to regulate flow. The synthetic wastewater was remained 20 hours constant in order to eliminate the residual chlorine.

A first order plug flow model based on nitrate removal was used and it is described by the following equation ${ }^{[6]}$ :

$\mathrm{As}=\frac{\mathrm{Q} *\left(\ln \mathrm{C}_{\mathrm{o}}-\ln \mathrm{C}_{\mathrm{e}}\right)}{\mathrm{K}_{\mathrm{t}} * \mathrm{~d} * \mathrm{n}}$

The value of $\mathrm{K} t$ is give by:

$\mathrm{K}_{\mathrm{t}}=1.15^{(\mathrm{T}-20)}$

Where:

$\mathrm{A}=\operatorname{Area}\left(\mathrm{m}^{2}\right)$

$\mathrm{Q}=$ Average flow $\left(\mathrm{m}^{3}\right.$ day $\left.^{1}\right)$

$\mathrm{C}_{\mathrm{o}}=$ Influent $\mathrm{NO}_{3}\left(\mathrm{mg} \mathrm{L}^{1}\right)$

$\mathrm{C}_{\mathrm{e}}=$ Effluent $\mathrm{NO}_{3}\left(\mathrm{mg} \mathrm{L}^{1}\right)$

$\mathrm{K}_{\mathrm{t}}=$ Temperature-dependent rate constant

$\mathrm{d}=$ Depth of gravel bed

$\mathrm{n}=$ Porosity

According to the average temperature of the site and knowing $\mathrm{n}$ and $\mathrm{d}$ we can decide the area.

For $\mathrm{t}=25, \mathrm{~K}_{\mathrm{t}}=1.15^{[25-20]}=2.011, \mathrm{~A}=0.65\left(\mathrm{~m}^{2}\right)$, $\mathrm{C}_{0}=100\left(\mathrm{mg} \mathrm{L}^{1}\right), \mathrm{C}_{\mathrm{e}}=5\left(\mathrm{mg} \mathrm{L}^{1}\right), \mathrm{d}=0.4(\mathrm{~m})$ and $\mathrm{n}=$ $35 \%$, the value of $Q$ is computed using Eq. 1 and it is found to be $0.060 \mathrm{~m}^{3}$ day'.

The amount of evapotranspiration is calculated and found to be $7 \mathrm{~mm}$ day ${ }^{1}$ for each cell, therefore value of $\mathrm{Q}$ for the four cells is found to be equal to $\mathrm{Q}=0.078 \mathrm{~m}^{3}$ day. HRT and HLR can be calculated using the following equations: 
$\mathrm{HRT}=\frac{\mathrm{A} \times \mathrm{d} \times \mathrm{n}}{\mathrm{Q}}$

$\operatorname{HLR}=\frac{\mathrm{Q}}{\mathrm{A}}$

Where:

HRT $=$ Hydraulic retention time

$\mathrm{HLR}=$ Hydraulic loading rate

The HRT and HLR can be calculated and their values were found to be 1.2 days and $0.12 \mathrm{~m}^{\text {day }}{ }^{1}$, respectively.

The systems were installed in April 2007. After two month form the planting date, the wastewater was operated into the system and water samples were then collected for 3 months. Water samples were taken from inflow, outflow and the sampling pipes every two week in order to measure $\mathrm{TP}, \mathrm{NO}_{3}-\mathrm{N}, \mathrm{Zn}, \mathrm{Pb}$ and $\mathrm{Cd}$. The analytical methods were referenced by ${ }^{[7]}$.

Statistical test: Statistical analyses were performed using SPSS 15 for Windows. Normality of the distribution of the metal concentration in the influent and effluent was tested by means of the KolmogorovSmirnov test of normality $(\alpha=0.05)$. All concentrations in the water were normally distributed. Significant differences between inflow and outflow water with regard to concentrations, was determined by the paired-samples t-test. Also the Duncan's Multiple Range test was run to determine the significant differences between 4 treatments. The same test was run to determine significant differences between location 1, 2 and 3 (effluent) in each cell. Pearson correlation coefficients $(\alpha=0.05)$ were determined between mean concentrations of wastewater of the different sampling time.

\section{RESULTS}

All macrophytes were found tolerant under the tested conditions. It was not possible to continuously monitor the variable flow rate in the outlet of the cells; therefore the removal efficiency was determined from concentrations and not from loadings. Both influent and effluent concentrations and removal statistics of TP, $\mathrm{NO}_{3}-\mathrm{N}$ and $\mathrm{Zn}$ are shown in Table 1. Although it is seen that the mean outflow concentration values are not statistically different among the 4 cells, but concentration reduction was statistically significant in all treatments.

As for nitrate removal, the mean outflow concentration of all the four cells shows that the difference is not statistically significant, as proven by the statistical tests. The unplanted cell with gravel $(\mathrm{G})$ had a removal efficiency of (86\%). The unplanted cell with gravel $(\mathrm{G})$ had a removal efficiency of $(86 \%)$. Similarly, the cell with zeolite $(10 \%)$ and gravel, without vegetation $(Z)$ had a removal efficiency of $(88.5 \%)$, while the other two planted cells ZP and GP had removal efficiencies of (81\%) and (77.6\%), respectively (Figure 2). A comparison of the inflow and outflow concentrations of $\mathrm{NO}_{3}-\mathrm{N}$ during the study period is shown in Figure 3. It indicates that the planted and unplanted cells show a significant reduction in $\mathrm{NO}_{3}-\mathrm{N}$ concentration. Nevertheless, it is obvious that the planted cells (ZP and GP) had lower removal efficiency as compared to the unplanted ones ( $Z$ and $G)$. In the case of phosphorus removal, the planted system with $(10 \%)$ zeolite + gravel as a substrate $(\mathrm{ZP})$ had a removal efficiency of $(92.7 \%)$.

Table 1: Total concentrations in the inflow and outflow of systems together with standard deviation (SD), range and removal efficiency

\begin{tabular}{|c|c|c|c|c|c|}
\hline & Variable & & $\mathrm{NO}_{3}-\mathrm{N}$ & $\mathrm{P}$ & $\mathrm{Zn}$ \\
\hline Influent & I & Mean \pm SD & $79.3 \pm 32.4$ & $10.5 \pm 1.04$ & $806 \pm 2.7$ \\
\hline \multirow[t]{6}{*}{ Concentration $(\mathrm{mg} \mathrm{I})$} & & Range & $110-20$ & $12.0-9.0$ & $12.0-5.0$ \\
\hline & A & Mean \pm SD & $17.71 \pm 9.34 \mathrm{a}$ & $0.76 \pm 0.58 \mathrm{c}$ & $0.011 \pm 0$ \\
\hline & & Rnge & $30-2$ & $1.7-0$ & $0.047-0$ \\
\hline & & Removal (\%) & 79.19 & 93.12 & 99.9 \\
\hline & & Mean \pm SD & $9.3 \pm 4.8 \mathrm{a}$ & $1.95 \pm 0.7 \mathrm{ab}$ & $0.019 \pm 0.018 \mathrm{a}$ \\
\hline & B & Range & $19.5-4.5$ & $3-0.83$ & $0.055-0$ \\
\hline Effluent & & Removal (\%) & 86.58 & 81.76 & 99.76 \\
\hline \multirow[t]{6}{*}{ Concentration $\left(\mathrm{mg} \mathrm{\textrm {I } ^ { 1 }}\right)$} & & Mean \pm SD & $15.14 \pm 8.27 \mathrm{a}$ & $1.14 \pm 0.63 b c$ & $0.022 \pm 0.019 \mathrm{a}$ \\
\hline & $\mathrm{C}$ & Range & $28-1$ & $2-0.33$ & $0.057-0$ \\
\hline & & Removal (\%) & 82.39 & 89.47 & 99.71 \\
\hline & & Mean \pm SD & $11.0 \pm 2.6 \mathrm{a}$ & $2.5 \pm 1.1 \mathrm{ab}$ & $0.037 \pm 0.019 \mathrm{a}$ \\
\hline & $\mathrm{D}$ & Range & $13-6$ & $4.2-1.33$ & $0.062-0$ \\
\hline & & Removal (\%) & 83.38 & 76.65 & 99.52 \\
\hline
\end{tabular}

Note: Means with the same letter(s) in each column are not significantly different, I = Inflow 


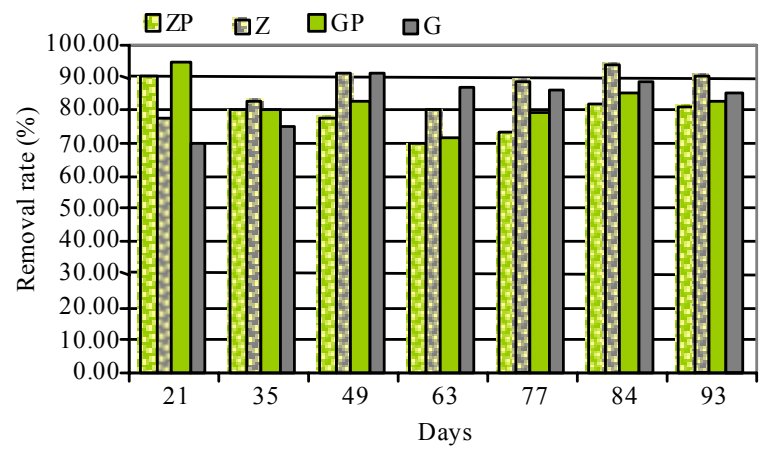

Fig. 2: $\mathrm{NO}_{3}-\mathrm{N}$ removal efficiency during the study period

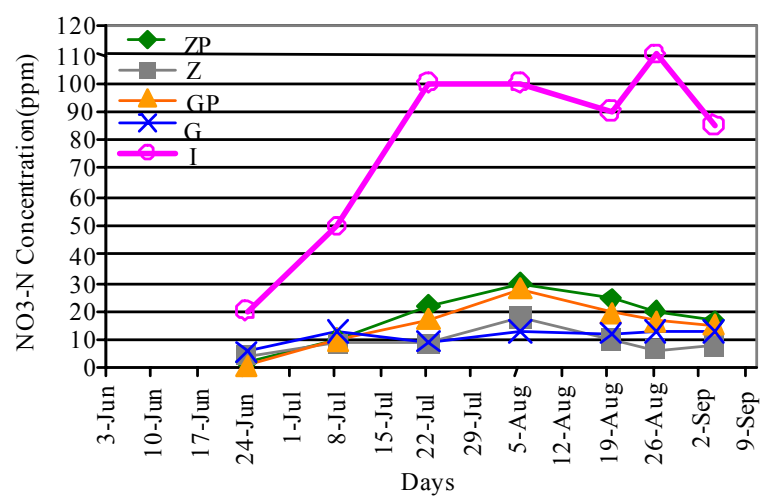

Fig3: Inflow and outflow concentration of $\mathrm{NO}_{3}-\mathrm{N}$ during the operation period

The cell with the same substrate without vegetation (Z) had a removal efficiency of (81.4\%). And the other two systems with gravel media (GP and G) had removal efficiency of $(89 \%)$ and $(76 \%)$ which refers to a planted and unplanted system respectively. The removal efficiency of $\mathrm{P}$ in each sampling during the study period is shown in Fig 4.

The same result got from mean values can be obtained from Figure 4. The experimental results of $P$ inflow and outflow concentration levels are shown in Fig 5. The outflow concentrations had a significant reduction in comparison with the inflow concentration levels. A much better removal efficiency of planted cells (almost 12\%) is shows in Figure 5. The concentrations of $\mathrm{P}$ in the influent were very low with average value of $1.5 \mathrm{mg} \mathrm{L}^{-1}$. The same result got from mean values can be obtained from Figure 4. The experimental results of $\mathrm{P}$ inflow and outflow concentration levels are shown in Fig 5. The outflow concentrations had a significant reduction in comparison with the inflow concentration levels A much better removal efficiency of planted cells (almost $12 \%$ ) is shows in Fig 5.

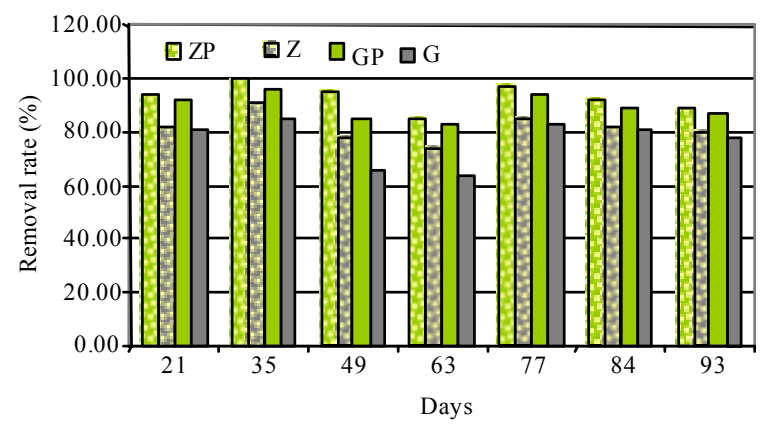

Fig 4: P removal efficiency during the study period

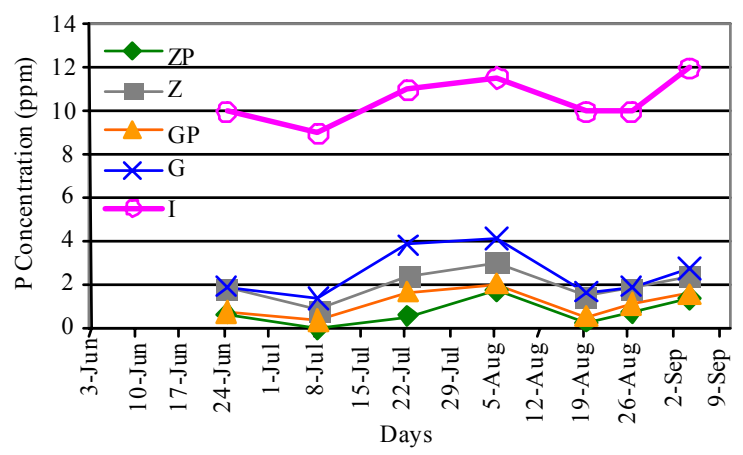

Fig 5: Inflow and outflow concentration of P during the operation period

The concentrations of $\mathrm{P}$ in the influent were very low with average value of $1.5 \mathrm{mg} \mathrm{L}^{-1}$. It was also found that $\mathrm{P}$ had a regular behavior during the study period which is shown by the relatively low standard deviation of the efficiency values Table 1 .

The removal efficiency and the concentrations of $\mathrm{Zn}$ in the influent and effluent are shown in Table 1. Based on the finding, the removal rates of heavy metals were found to be almost $(100 \%)$. The concentrations of $\mathrm{Cd}$ and $\mathrm{Pb}$ in the effluent were lower than the detection limit, indicating that the systems were highly efficient in removing heavy metals from polluted water. Hence, the following section will put forward a discussion of the effect of $\mathrm{Zn}$. The planted cell with zeolite and gravel (ZP) had the highest removal efficiency of $(99.89 \%)$, whereas, the cell with the same substrate without vegetation $(Z)$ had the second removal efficiency of $(99.76 \%)$. The other two units with gravel, with and without vegetation (GP and G) had removal efficiencies of $(99.70 \%)$ and $(99.52 \%)$, respectively Figure 6 . As for $\mathrm{Zn}$, a decrease in the total concentration between the influent and effluent is observed during monitoring, as shown in Figure 7.

Table 2 shows the values of pollutant concentrations along the four units for the entire operation period. 
Am. J. Environ. Sci., 5 (1): 99-105, 2009

Table 2: Variation of concentration along the cell's length

\begin{tabular}{|c|c|c|c|c|c|c|c|}
\hline & & \multicolumn{3}{|c|}{$\mathrm{ZP}$} & \multicolumn{3}{|l|}{ Z } \\
\hline & & ZP1 & $\mathrm{ZP} 2$ & $\mathrm{ZP} 3$ & $\mathrm{Z1}$ & $\mathrm{Z} 2$ & $\mathrm{Z3}$ \\
\hline \multirow[t]{4}{*}{$\mathrm{NO}_{3}$} & Mean \pm SD & $14.5 \pm 2.5$ & $13.3 \pm 1.2$ & $17.71 \pm 9.34$ & $10.7 \pm 2.6$ & $9.3 \pm 4.8$ & \\
\hline & Range & $25-5.5$ & $20-10$ & $30-2$ & $15-5$ & $25.5-5.5$ & $19.5-4.5$ \\
\hline & Removal (\%) & 81.71 & 83.15 & 77.66 & 86.40 & 78.38 & 88.47 \\
\hline & Mean \pm SD & $2.1 \pm 0.36$ & $1.37 \pm 0.26$ & $0.76 \pm 0.58$ & $2.7 \pm 0.27$ & $2.13 \pm 0.26$ & $1.95 \pm 0.7$ \\
\hline \multirow[t]{3}{*}{ P } & Range & $4-1.1$ & $2.5-0.66$ & $1.7-0$ & $3.5-1.93$ & $3.2-1$ & $3-0.83$ \\
\hline & Removal (\%) & 79.92 & 86.95 & 92.78 & 74.49 & 79.71 & 81.39 \\
\hline & Mean \pm SD & $0.28 \pm 0.01$ & $0.055 \pm 0.014$ & $0.011 \pm 0.017$ & $0.1 \pm 0.15$ & $0.017 \pm 0.045$ & $0.019 \pm 0.018$ \\
\hline \multirow[t]{5}{*}{$\mathrm{Zn}$} & Range & $0.65-0.015$ & $0.111-0$ & $0.047-0$ & $0.77-0.014$ & $0.14-0$ & $0.055-0$ \\
\hline & Removal (\%) & 97.11 & 99.34 & 99.90 & 98.53 & 99.47 & 99.76 \\
\hline & & \multicolumn{3}{|c|}{ GP } & G & & \\
\hline & & GP1 & GP2 & GP3 & G1 & G2 & G3 \\
\hline & Mean \pm SD & $12.1 \pm 3.2$ & $10.5 \pm 2.2$ & $15.14 \pm 8.27$ & $16.7 \pm 1.5$ & $12.3 \pm 1.5$ & $11.0 \pm 2.6$ \\
\hline \multirow{3}{*}{$\mathrm{NO}_{3}$} & Range & $22-0.5$ & $18.5-2$ & $28-1$ & $21.5-9.5$ & $15.5-5$ & $13-6$ \\
\hline & Removal (\%) & 84.68 & 84.76 & 80.90 & 78.92 & 84.50 & 83.38 \\
\hline & Mean \pm SD & $2.66 \pm 0.47$ & $1.84 \pm 0.38$ & $1.14 \pm 0.63$ & $3.27 \pm 0.39$ & $2.7 \pm 0.4$ & $2.5 \pm 1.1$ \\
\hline \multirow[t]{2}{*}{$\mathrm{Zn}$} & Range & $0.723-0.016$ & $0.277-0$ & $0.057-0$ & $1.2-0.035$ & $0.575-0$ & $0.062-0$ \\
\hline & Removal (\%) & 96.62 & 99.30 & 99.71 & 96.55 & 98.73 & 99.52 \\
\hline
\end{tabular}

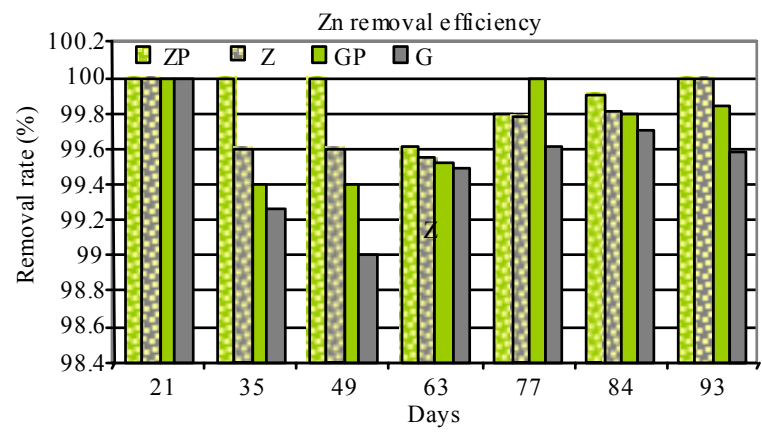

Figure 6: Zn removal efficiency

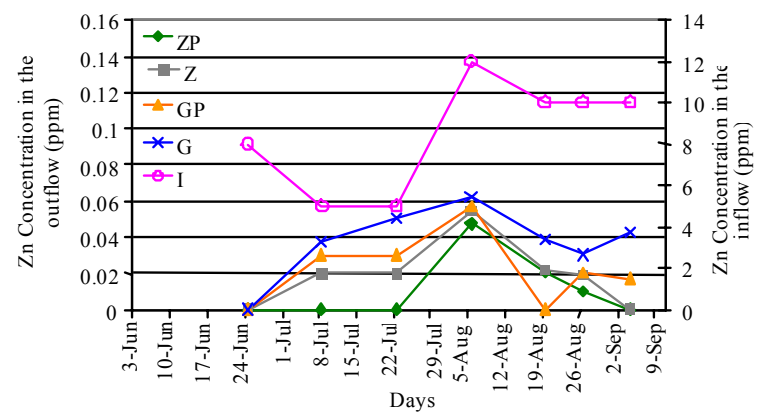

Fig 7: Inflow and Outflow Concentrations of $\mathrm{Zn}$ during the Operation Period

It is observed that most of the pollutants are mainly removed in the first one-third of the constructed wetland length. In all four cells more than $(82 \%)$ of $\mathrm{NO}_{3}-\mathrm{N}$ removal occurred in the first and third parts. The concentration of $\mathrm{NO}_{3}-\mathrm{N}$ in the four cells which is below $20 \mathrm{mg} \mathrm{L}^{1}$ between the inlet A decrease of $(0.3 \%)$ and $(0.06 \%)$ in average was observed in the second. It can be seen that the $\mathrm{NO}_{3}-\mathrm{N}$ reduction has a regular function only in cell $G$ which shows a gradual removal. Other cells did not show regular reduction along the system which may be occurred due to experimental error. Also it should be noted that the behavior of nitrate is difficult to explain because of different functions of $\mathrm{N}$ especially in the presence of the plant, so it is not possible to define a particular function for cell ZP and GP. More than (74\%) of P removal occurred in the first one-third part of all cells. An average of $(6 \%)$ and $4 \%$ reduction was observed in the other two sections. In all cells a gradual reduction is seen which shows an ordinary function for P.

In planted cells (ZP and GP) a sharper decline is observed due to plant uptake. Zeolite presence in cell $\mathrm{ZP}$ and $\mathrm{Z}$ is the reason for less concentration shown in Fig8 in all locations.

For $\mathrm{Zn}$ in all four cells more than (97\%) of $\mathrm{Zn}$ removal occurred in the first one- third part of cells. An average reduction of $(2 \%)$ and $(0.5 \%)$ was observed in the second and third parts along the cells.

and location 1. In the rest part of the cells there is not a significant change in concentrationsone-third part of the cells.

\section{DISCUSSION}

Less treatment efficiencies were observed in the systems with media only ( $\mathrm{Z}$ and $\mathrm{G}$ ) indicating that wetland plants play an important role in pollution removal. Although the outflow concentrations from $\mathrm{Z}$ and $G$ cells are higher than planted cells, significant amounts of contaminants were removed in those systems in the absence of wetland plant. This suggests that the microbial and physical/chemical processes may also result in the removal of pollutants because the media create suitable environment for microbial 
growth. Biodegradation, sedimentation and sorption were the major pollutant removal mechanisms in the systems with media only. The important mechanisms for the removal of $\mathrm{N}$ are microbial activity (ammonification, nitrification and denitrification), plant uptake, sedimentation and ammonia volatilization ${ }^{[8-10]}$. Nitrification/denitrification and ammonification occur simultaneously in most CWs, but the extent of individual processes differs among the systems. The higher nitrate concentrations in vegetated cells are thus likely due to the root zone effect (RZE) which let more oxygen to be transferred into the soil in order to precede the activities of nitrifying bacteria and nitrification ${ }^{[11,12]}$. In other words, some vegetated beds of CWs provide high rate of nitrification, thus creating additional $\mathrm{NO}_{3}-\mathrm{N}$, which does not undergo denitrification due to unfavourable oxygen conditions for this process; so, nitrification produces more nitrate than what has been removed by denitrification. It is also interesting to note that the harvested mass from the $\mathrm{ZP}$ unit was about 1.3 times that of the GP unit, which may explain the increased nitrate amount in this unit, due to higher RZE which let more oxygen transferred into the soil to precede the activities of nitrifying bacteria and nitrification. In gravel and zeolite bed cells, as compared to gravel bed cells, the higher removal efficiency could be due to the cation exchange capacity of zeolite which affects ammonia in the system by adsorption process, in which the ammonia is exchanged by $\mathrm{Na}^{+[13,14]}$. In this way, zeolite can therefore reduce the amount of $\mathrm{NH}_{4}$ which can affect the amount of $\mathrm{NO}_{3}$ produced in the nitrification process. Some researches show a removal of $(82 \%)$ to $(99 \%)$ for $\mathrm{NO}_{3}-\mathrm{N}^{[15]}$, $(89 \%)$ for nitrate ${ }^{[16]}$ and $(70.73 \%)$ for $\mathrm{NO}_{3}-\mathrm{N}^{[17]}$. Constructed wetlands with subsurface flow have the major potential for phosphorus removal as adsorption and precipitation of $\mathrm{P}$ is effective in such systems where wastewater gets in contact with filtration substrate via these mechanisms. So, HSSF systems have higher potential for $\mathrm{P}$ reduction because the substrate is constantly flooded and there is not much fluctuation in redox potential in the bed ${ }^{[3]}$.

\section{CONCLUSION}

The contamination of nutrients and heavy metals in water environment is a serious problem which threatens not only the aquatic ecosystems, but also human health. The present study provides evidences which prove that these treatment systems can be used effectively for decontamination of water with nutrient and $\mathrm{Zn}, \mathrm{Pb}$ and Cd pollution. The emergent wetland plants (Phragmites Australis and Juncus Inflexus) have been shown to survive and perform well in treating synthetic wastewater, while Zeolite and gravel materials provide a suitable plant growth medium in constructed wetlands as an alternative to conventional sand and gravel substrates. The wetland shows strong potential for the reduction of TP since TP reductions resemble efficiencies found in other similar studies. Constructed wetland cells can be expected to remove $\mathrm{P}$ and the removal efficiencies range from as high as $(96.12 \%)$ to as low as $(76.65 \%)$ while higher removal was observed in vegetated cell with a substrate of zeolite and gravel. The characteristics of the media type selected in this system (zeolite), containing higher amounts of $\mathrm{Ca}, \mathrm{Al}$ and $\mathrm{Fe}$ oxides, was inferred to be a factor causing such high removal of $\mathrm{P}$ by adsorption. Therefore, it can be used effectively as a media, alone or in combination with other materials in CWs. The plant uptake was also concluded to be a factor in the P removal due to the higher removal efficiency of the planted cells. For the removal of $\mathrm{NO}_{3}-\mathrm{N}$, the gravel-bed wetland system without vegetation was found to be the optimal one in this study. The RZE of plants was identified to be the factor causing the increase of $\mathrm{NO}_{3}-\mathrm{N}$ tested in the effluent of the vegetated systems. Meanwhile, the removal of $\mathrm{NO}_{3}-\mathrm{N}$ was also more significant in unplanted zeolite and gravel-bed wetland systems than in the unplanted gravel-bed systems through cation exchange capacity of zeolite, which affected ammonia by the adsorption process. In this process, the ammonia is exchanged by $\mathrm{Na}^{+}$and the reduction in ammonia concentration would reduce the $\mathrm{NO}_{3}-\mathrm{N}$ amount produced by nitrification. As for $\mathrm{Zn}$ removal, the planted cell with zeolite and gravel had the highest removal efficiency, while the system with the same substrate without vegetation had the 2 nd highest removal efficiency and the other two units with gravel, with and without vegetation had lower removal efficiencies. It can be concluded from this research that adsorption in the constructed wetland was the principal process for the removal of $\mathrm{Zn}$ from the wastewater, while the plant tissues took up only small amounts of metals. It is also demonstrated that most of the removal occurred in the first one third part of the cells near the inlet by chemical mechanisms. The differences in the overall efficiency are therefore related to the biochemical processes operating along the length of the bed.

\section{REFERENCES}

1. Gleick, P.H., 1993. Water and conflict: Fresh water resources and international security. Int. Secur., 18: 79-112. 
2. Kivaisi, A.K., 2001.The potential for constructed wetlands for wastewater treatment and reuse in developing countries. Ecol. Eng., 16: 545-560. : http://www.sciencedirect.com/science/article/B6V FB-

427KM298/2/69b59c84d26593c3f579763d600bff5 1

Doi: $10.1016 / \mathrm{S} 0925-8574(00) 00113-0$.

3. Vymazal, J., 2006.Removal of nutrients in various types of constructed wetlands. Sci Total Environ.380:48-65.

http://www.sciencedirect.com/science/article/B6V7 84M7K9MY4/2/fb43994ce7bf34149cb0ca3e9dcdc bd2.Doi: 10.1016/j.scitotenv.2006.09.014

4. Kadlec, R.H. and R.L. Knight, 1996.Treatment Wetlands.CRC Press, Boca Raton, FL, USA. pp: 893. 2nd Edn. ISBN 1566703425, 9781566703420 .

5. Gottschall, N., C. Boutin, A. Crolla, C. Kinsley and P. Champagne, 2007.The role of plants in the removal of nutrients at a constructed wetland treating agricultural dairy wastewater. Ecol. Eng. Ontario Canada.29:154-163. URL:http://www.sciencedirect.com/science/article/ B6VFB4MMFVNW1/2/de75959324cd96eb66d3f3 495c655cfa.Doi:10.1016/j.ecoleng.2006.06.004

6. Reed, S.C., R.W. Crites and E.J. Middlebrooks, 1995.Natural Systems for Waste Management and Treatment. 2nd Edn. McGraw-Hill, Inc, USA. ISBN: 0-07-060982-9.

7. APHA-AWWA-WPCF, 1995.Standard Methods for the Examination of Water and Wastewater.19th Edn. American Public Health Association, Washington DC.

8. Yang, L., H.T. Chang and M.L. Huang, 2001.Nutrient removal in gravel-and soil-based wetland microcosms with and without vegetation. Ecol. Eng., 18:91-105. http://www.sciencedirect.com/science/article/B6V FB43GBY4G7/2/01090a6b9ada184ab8656daa8f53 7714. Doi: 10.1016/S0925-8574(01)00068-4

9. Vymazal, J., 2002. The use of subsurfaceconstructed wetlands for wastewater treatment in the Czech Republic: Ten years experience. Ecol. Eng., 18: 633-646.

http://www.sciencedirect.com/science/article/B6V FB45H992R7/2/20bc35c69cb27a4d3a66f319a82a6 b14.Doi:10.1016/S0925-8574(02)00025-3

10. Al-Omari, A. and M. Fayyad, 2003. Treatment of domestic wastewater by subsurface flow constructed wetlands in Jordan. Desalination, 155: 27-39.

http://www.sciencedirect.com/science/article/B6TF X49G426P4/2/c56ba46af99cb33ec5dc1d0aaf62a43

5. Doi: 10.1016/S0011-9164(03)00236-4
11. Armstrong, J. and W. Armstrong, 1991.A convective through-flow of gases in Phragmites australis (Cav.) Trin. ex Steud.Aquatic Bot., 39L: 75-88.

http://www.sciencedirect.com/science/article/B6T4 F49155P12N/2/d175bab8b095d67ee9a526dab4c7e 7fb.Doi: 10.1016/0304-3770(91)90023-X

12. Brix, H. and H.H. Schierup, 1989. The use of macrophytes in water pollution control. Ambio, 18: 100-107.

13. Lahav, O. and M. Green, 1997.Ammonium removal using exchange and biological regeneration. Water Res.32:2019-2028. http://www.sciencedirect.com/science/article/B6V7 33TGNX9P5/2/8eeebdd3befc65e3be872db633138f 3e. Doi: 10.1016/S0043-1354(97)00453-3

14. Jung, J.Y., Y.C. Chung, H.S. Shin and D.H. Son, 2004.Enhanced ammonia nitrogen removal using consistent biological regeneration and ammonium exchange of zeolite in modified SBR process. Water Res.38:347-354.

http://www.sciencedirect.com/science/article/B6V7 34B0PPDK1/2/a10a071b101d8d3c4efb397fc4ff48 00.Doi:10.1016/j.watres.2003.09.025

15. Lin, Y.F., S.R. Jing, Y.D. Lee and T.W. Wang, 2002.Nutrient removal from aquaculture wastewater using a constructed wetlands system. Aquaculture, 209: 169-184.

http://www.sciencedirect.com/science/article/B6T4 D463FWM6D/2/1695e1100fd4424af982b26e9735 49e4. Doi:10.1016/S0044-8486(01)00801-8

16. Hadad, H.R., M.A. Maine and C.A. Bonetto, 2006. Macrophyte growth in a pilot-scale constructed wetland for industrial wastewater treatment. Chemosphere, 63:1744-1753.

http://www.sciencedirect.com/science/article/B6V7 44HHP39YG/2/37811d7b9e56c1ffd571248c6afa8c 22.Doi:10.1016/j.chemosphere.2005.09.014

17. Sim, Ch.H., M.K. Yusoff, B. Shutes, S. Ch.Ho and M. Mansor, 2007. Nutrient removal in a pilot and full scale constructed wetland, Putrajaya city, Malaysia. J.Environ.Manage. 88(2):307-317. http://www.sciencedirect.com/science/article/B6V7 44HHP39YG/2/37811d7b9e56c1ffd571248c6afa8c 22. Doi:10.1016/j.jenvman.2007.03.011 